Brit. J. industr. Med., 1962, 19, 131.

\title{
SERUM PROTEINS AND SERUM GLYCOPROTEINS IN THE DIFFERENTIAL DIAGNOSIS OF SILICOSIS AND SILICO-TUBERCULOSIS
}

\author{
BY \\ H. OYANGUREN, R. SILVA, A. ROSENKRANZ, and J. ISA \\ From the Occupational Health Section and the Biochemistry Laboratory of the Extraordinary \\ Chair of Introduction to Medicine, National Health Service, Santiago, Chile
}

(RECEIVED FOR PUBLICATION MAY 2, 1961)

\begin{abstract}
The serum proteins and glycoproteins in 73 males were investigated with the object of deciding which tests differentiated most clearly between "pure" silicosis and silico-tuberculosis. None of the tests was entirely satisfactory as, although significant differences between the averages for the various groups were found, the scatter of the individual results was so wide that the tests were not considered useful in individual cases.
\end{abstract}

Differentiation between "silicosis" and "silicotuberculosis" has usually been based on the finding of tubercle bacilli in the sputum, but it is not unreasonable to suppose that tuberculous pathology may be present in the lung concealed by the massive shadow without tubercle bacilli being found in the sputum. For this reason many attempts have been made to discover some simple way of determining the presence of the added tuberculous infection without resorting to lung puncture. Similar problems arise in progressive massive fibrosis of coal-miners where $43 \%$ can be shown to suffer from tuberculous infection at death but only between 1 and $2 \%$ are found to be infectious in life, and it seems reasonable to suppose that many such cases have tuberculous infection before it becomes overt in the sputum. The proof that a case is tuberculous is not only of value therapeutically, prognostically, and epidemiologically, but in nearly every country it assumes medico-legal importance.

There have been several accounts in the literature of attempts to find specific differences between silico-tuberculosis without a positive sputum and silico-tuberculosis with a positive sputum. The main work has been done on serum proteins by Vigliani, Boselli, and Pecchiai (1950), Beckmann, Antweiler, and Hilgers (1953), Prignot (1959), and Rosenkranz (1957), and on glycoproteins by Pernis and Clerici (1957), Sonnet and Prignot (1956) and Wang, Ts'ai, Chu, Wu, and Chang (1959). Most of these studies show differences in their average values between the different groups, some of which have reached the conventional limit of statistical significance, but there has always been a very large overlap in the value for the different groups. Our objective in this paper has been to study the differences between cases of silicosis and silico-tuberculosis and normal people, measuring not only the serum proteins and glycoproteins but also the electrophoretic pattern of the glycoproteins. This technique has not, as far as we know, been used on such cases before.

\section{Population Studied}

The populations on which tests were carried out were as follows:

Group 1.-Twenty physically healthy males drawn from a mental hospital.

Group 2.-Twenty "silicotic" males of various categories but without tubercle bacilli in their sputum, drawn from the Out-patients Clinic of the Occupational Health Service;

Group 3.-Thirteen males with silico-tuberculosis with tubercle in their sputum drawn from chest hospitals and sanatoria;

Group 4.- Twenty males with advanced tuberculosis who had never been exposed to silica dust, drawn from chest hospitals and sanatoria.

The mean age for each group was about 44 years with a range of 30 to 60 . Most of the tuberculous and silico-tuberculous cases were receiving antibiotic treatment. 
TABLE 1

SERUM GLYCOPROTEINS IN HEALTHY, SILICOTIC, SILICO-TUBERCULLOUS, AND TUBERCULỎUS SUBJECTS

\begin{tabular}{l|c|c|c|c}
\hline \multicolumn{1}{c|}{ Group } & $\begin{array}{c}\text { No. of } \\
\text { Cases }\end{array}$ & $\begin{array}{c}\text { Average } \\
\text { (mg. tyrosin/ } \\
\text { 100 ml. serum) }\end{array}$ & $\begin{array}{c}\text { Standard } \\
\text { Deviation }\end{array}$ & Range \\
\hline Healthy & 20 & $2 \cdot 3$ & $0 \cdot 48$ & $1 \cdot 3-3 \cdot 3$ \\
Silicotic & 20 & $3 \cdot 2$ & $0 \cdot 82$ & $1 \cdot 8-5 \cdot 1$ \\
Silico-tuberculous & 13 & $3 \cdot 4$ & 0.47 & $2 \cdot 7-4 \cdot 2$ \\
Tuberculous & 20 & $4 \cdot 3$ & $2 \cdot 21$ & $1 \cdot 8-9 \cdot 6$ \\
\hline
\end{tabular}

TABLE 1a

PROBABILITIES FROM TABLE

\begin{tabular}{|c|c|c|c|c|c|c|}
\hline \multirow{2}{*}{ Group } & \multicolumn{2}{|c|}{ Healthy } & \multicolumn{2}{|c|}{ Silicotic } & \multicolumn{2}{|c|}{ Tuberculous } \\
\hline & $\mathbf{t}$ & p (\%) & $\mathbf{t}$ & $\mathrm{p}(\%)$ & $\mathbf{t}$ & $\mathbf{p}$ \\
\hline $\begin{array}{l}\text { Silicotic } \\
\text { Tuberculous } \\
\text { Silico-tuberculous }\end{array}$ & $\begin{array}{l}4 \cdot 69 \\
4 \cdot 25 \\
6 \cdot 41\end{array}$ & $\begin{array}{l}<0.1 \\
<0.1 \\
<0.1\end{array}$ & $\begin{array}{l}\overline{2 \cdot 07} \\
0 \cdot 38\end{array}$ & $\begin{array}{l}\overline{<5} \\
\text { N.S. }\end{array}$ & $\overline{1.49}$ & $\overline{\bar{N} . S}$ \\
\hline
\end{tabular}

\section{Methods}

All cases had a clinical examination; the pathological cases had a standard radiograph, and for the apparently healthy cases, fluoroscopy or radiophotography was carried out. In addition all cases had tests on a fasting specimen of blood $(20 \mathrm{ml}$.).

The following tests were carried out on the blood.

\section{Serum Levels.}

(a) Glycoproteins (mucoproteins) were estimated by the method of Winzler (1955). The results were expressed as $\mathrm{mg}$. tyrosin per $100 \mathrm{ml}$. serum.

(b) Protein-bound hexoses were estimated according to the original method of Winzler (1955). The results were expressed in $\mathrm{mg}$. per $100 \mathrm{ml}$. serum. The readings were made by means of the Coleman Spectrophotometer, Model 14. The total protein level was not measured.

Serum Electrophoresis.-The tests for total proteins and glycoproteins were carried out according to the method of Morales (1958), working with the Elphor apparatus and Bender and Hobein paper No. 2043-a. The readings were performed in the Beckman-Spinco Analitrol automatic densitometer.
TABLE 2

SERUM PROTEIN-BOUND HEXOSES IN HEALTHY, SILICOTIC, SILICO-TUBERCULOUS, AND TUBERCULOUS SUBJECTS (mg. per $100 \mathrm{ml}$. serum)

\begin{tabular}{|c|c|c|c|c|}
\hline Group & $\begin{array}{l}\text { No. of } \\
\text { Cases }\end{array}$ & Average & $\begin{array}{l}\text { Standard } \\
\text { Deviation }\end{array}$ & Range \\
\hline $\begin{array}{l}\text { Healthy } \\
\text { Silicotic } \\
\text { Silico-tuberculous } \\
\text { Tuberculous }\end{array}$ & $\begin{array}{l}20 \\
20 \\
13 \\
20\end{array}$ & $\begin{array}{l}120.0 \\
131.2 \\
155.1 \\
157.8\end{array}$ & $\begin{array}{r}8 \cdot 60 \\
18 \cdot 42 \\
21 \cdot 48 \\
34 \cdot 53\end{array}$ & $\begin{array}{l}102 \cdot 7-132 \cdot 4 \\
106 \cdot 5-190 \cdot 3 \\
128 \cdot 4-186 \cdot 5 \\
110 \cdot 8-237 \cdot 8\end{array}$ \\
\hline
\end{tabular}

TABLE $2 \mathrm{a}$

PROBABILITIES FROM TABLE 2

\begin{tabular}{|c|c|c|c|c|c|c|}
\hline \multirow{2}{*}{ Group } & \multicolumn{2}{|c|}{ Healthy } & \multicolumn{2}{|c|}{ Silicotic } & \multicolumn{2}{|c|}{ Tuberculous } \\
\hline & $\mathbf{t}$ & p (\%) & $t$ & p (\%) & $\mathbf{t}$ & $\mathbf{p}$ \\
\hline $\begin{array}{l}\text { Silicotic } \\
\text { Tuberculous } \\
\text { Silico-tuberculous }\end{array}$ & $\begin{array}{l}2.52 \\
4.75 \\
6.80\end{array}$ & $\begin{array}{l}<2 \\
<0.1 \\
<0.1\end{array}$ & $\begin{array}{l}3 \cdot \overline{3} \\
3.49\end{array}$ & $\begin{array}{l}<1 \\
<1\end{array}$ & $\overline{\overline{0}}$ & $\overline{\overline{\text { N.S.S}}}$ \\
\hline
\end{tabular}

\section{Results}

Glycoproteins.-Table 1 shows the average values together with their standard deviations for the serum glycoproteins; probabilities of significant differences are given in Table 1a. The results confirm those found by others in that there are large differences in the average values for the various groups, and that the scatter in the groups is so large that the determination is of no particular value diagnostically in any individual case. It is also of interest that the differences between the silicotic and silico-tuberculous on the one hand, and the silico-tuberculous and the tuberculous on the other do not reach the conventional levels of statistical significance.

Protein-bound Hexoses.-Table 2 summarizes results of the estimations of serum-bound hexoses; probabilities of significant differences are given in Table 2a. The results follow the same pattern as those in Table 1 , but in this series there is a statistically significant difference between the silicotic and

TABLE 3

MEAN VALUES AND RANGES OF SERUM PROTEIN FRACTIONS IN HEALTHY, SILICOTIC, SILICO-TUBERCULOUS, AND TUBERCULOUS SUBJECTS (mg. per $100 \mathrm{ml}$. serum)

\begin{tabular}{|c|c|c|c|c|c|c|}
\hline \multirow{2}{*}{ Group } & \multirow{2}{*}{ No. of Cases } & \multirow{2}{*}{ Albumin } & \multicolumn{4}{|c|}{$\%$ Globulin } \\
\hline & & & $a_{1}$ & $a_{2}$ & $\beta$ & $\gamma$ \\
\hline $\begin{array}{l}\text { Healthy } \\
\text { Silicotic } \\
\text { Silico-tuberculous } \\
\text { Tuberculous }\end{array}$ & $\begin{array}{l}20 \\
20 \\
13 \\
20\end{array}$ & $\begin{array}{l}53 \cdot 5(44 \cdot 9-66 \cdot 1) \\
51 \cdot 7(36 \cdot 6-68 \cdot 0) \\
41 \cdot 1(25 \cdot 6-51 \cdot 2) \\
46 \cdot 3(25 \cdot 9-61 \cdot 8)\end{array}$ & $\begin{array}{l}4 \cdot 7(1 \cdot 7-6 \cdot 9) \\
4.9(1 \cdot 6-8 \cdot 8) \\
5 \cdot 7(3 \cdot 7 \cdot 7 \cdot 5) \\
6 \cdot 0(1 \cdot 9-12 \cdot 6)\end{array}$ & $\begin{array}{r}9 \cdot 1(5 \cdot 3-13 \cdot 2) \\
9 \cdot 8(7 \cdot 1-13 \cdot 0) \\
13 \cdot 7(8 \cdot 0-17.7) \\
11 \cdot 2(7 \cdot 6-16 \cdot 4)\end{array}$ & $\begin{array}{l}12 \cdot 8(6 \cdot 9-17 \cdot 2) \\
13 \cdot 2(7 \cdot 1-19 \cdot 0) \\
13 \cdot 6(7 \cdot 5-20.1) \\
12 \cdot 7(9 \cdot 0-15 \cdot 7)\end{array}$ & $\begin{array}{l}19 \cdot 9(13 \cdot 8-26 \cdot 0) \\
20 \cdot 4(12 \cdot 7-32 \cdot 3) \\
26.0(19 \cdot 6-41 \cdot 6) \\
23 \cdot 8(12 \cdot 9-37 \cdot 1)\end{array}$ \\
\hline
\end{tabular}

Ranges are given in parentheses. 
TABLE 4

MEAN VALUES AND RANGES OF SERUM GLYCOPROTEIN FRACTIONS IN HEALTHY, SILICOTIC, SILICO-TUBERCULOUS, AND TUBERCULOUS SUBJECTS

\begin{tabular}{l|c|c|c|}
\hline \multicolumn{1}{c|}{ Group } & No. of Cases & \multicolumn{2}{c}{ Glycoprotein } \\
\cline { 2 - 3 } & & $\alpha_{2}$ & $\beta$ \\
\hline Healthy & 20 & $20 \cdot 7(8 \cdot 0-39 \cdot 2)$ & $30 \cdot 2(13 \cdot 4-51 \cdot 8)$ \\
Silicotic & 20 & $24 \cdot 9(10 \cdot 5-57 \cdot 9)$ & $33 \cdot 2(11 \cdot 5-56 \cdot 8)$ \\
Silico-tuberculous & 13 & $23 \cdot 9(7 \cdot 6-34 \cdot 2)$ & $23 \cdot 7(10 \cdot 0-43 \cdot 9)$ \\
Tuberculous & 20 & $23 \cdot 4(4 \cdot 7-46 \cdot 0)$ & $49 \cdot 1(32 \cdot 0-67 \cdot 7)$ \\
\hline
\end{tabular}

Ranges are given in parentheses.

silico-tuberculous groups, but there is still a large overlap between individual cases.

Electrophoresis of Total Proteins.-Table 3 summarizes the results of the electrophoresis of total proteins. There is a gradual increase in the $a_{1}, \alpha_{2}$, and $\gamma$ fractions through the various groups, while the $\beta$ fraction remains relatively constant. This confirms the work of the authors previously cited.

Electrophoresis of Glycoproteins.-The differences between groups are slight and more irregular than those for total proteins (Table 4). None of the differences achieves the conventional level of statistical significance.

\section{Discussion}

Our results confirm previous findings that none of the tests is satisfactory in individual cases owing to the wide overlap between the various groups. Our results with the electrophoresis of glycoproteins, which has not previously been used in this connexion, do not suggest that this method is any better at differentiating between the groups than the others; if anything, it is worse.

The authors are indebted to Dr. H. Behm and Dr. R. Plaut, of the Chair of Statistics, School of Public Health, University of Chile, for their advice in the statistical analysis. We are also indebted to our colleagues in Hospitals and Sanatoria who collaborated over the clinical cases.

\section{REFERENCES}

Beckmann, H., Antweiler, H., and Hilgers, A. (1953). Beitr. SilikoseForsch., Heft 20 , p. 1 .

Morales, J. A. (1958). Estudios de las Proteinas del Suero Humano por Medio de Electroforesis en Papel. Edit. Universitaria, Santiago, Chile.

Pernis, B., and Clerici, E. (1957). Med. d. Lavoro, 48, 238 bis. Prignot, J. (1959). La Tuberculose des Houilleurs, Edit. "Arscia"

Brussels.
Rosenkranz, K. A. (1957). Beitr. Silikose-Forsch., Heft 48, p. 1.

Sonnet, J., and Prignot, J. (1956). Arch. Gewerbepath. Gewerbehyg.,

Vigliani, E. C., Boselli, A., and Pecchiai, L. (1950). Med. d. Lavoro,

Wang, S. C., Ts'ai, L. W., Chu, S. Y., Wu, Y. Y., and Chang, C. Y. (1959). Chin. med.J., 79, 531.

Winzler, R. J. (1955). Meth. biochem. Anal., 2, 279. 